\title{
KEPUASAN MASYARAKAT PADA PELAYANAN DI KANTOR CAMAT BAYUNG LENCIR KECAMATAN BAYUNG LENCIR KABUPATEN MUSI BANYUASIN
}

\author{
Oleh : \\ Muhlisin \\ Sekolah Tinggi Ilmu Ekonomi Rahmaniyah Sekayu \\ Email : Muhlisin.Stier@gmail.com
}

\begin{abstract}
Penelitian ini membahas tentang kepuasan masyarakat pada pelayanan di kantor camat Bayung Lincir, Kecamatan Bayung Lincir Kabupaten Musi Banyuasin. Hasil penelitian secara statistik yaitu, $Y=1,4718+0,3024 X_{1}+0,2418 X_{2}$. Nilai konstanta sebesar 1,4718, hal ini menunjukan bahwa apabila variabel $\mathrm{X}_{1}, \mathrm{X}_{2}$ nilainya 0 maka nilai $\mathrm{Y}=1,4718$. Nilai koefisien $\mathrm{X}_{1}$ (kualitas pelayanan) nilainya sebesar 0,3024. Hal ini membuktikan bahwa apabila nilai $\mathrm{X}_{1}$ meningkat sebesar 1 satuan atau $100 \%$ maka nilai variabel (Y) akan mengalami peningkatan sebesar 0,3024 dengan asumsi variabel independen lainnya konstan.Nilai koefisien $\mathrm{X}_{2}$ (semangat pegawai) nilainya sebesar 0.2418. Hal in membuktikan bahwa apabila nilai $\mathrm{X}_{2}$ meningkat 1 satuan atau $100 \%$ maka nilai variabel (Y) akan mengalami kenaikan sebesar 0.2418 dengan asumsi variabel independen lainnya konstan. Penelitian ini menyimpulkan ada pengaruh kualitas pelayanan dan semangat kerja terhadap kepuasan masyarakat.diKantor Camat Bayung Lencir Kecamatan Bayung Lencir Kabupaten Musi Banyuasin. Hasil pengujian menunjukan ada pengaruh yang signifikan antara kualitas pelayanan dan semangat kerja terhadap kepuasan masyarakat di Kantor Camat Bayung Lencir Kecamatan Bayung Lencir Kabupaten Musi Banyuasin. Kualitas pelayanan memiliki pengaruh yang lebih kecil dibandingkan dengan semangat kerja karyawan, sehingga Kantor Camat Bayung Lencir Kecamatan Bayung Lencir Kabupaten Musi Banyuasin perlu meningkatkan kualitas pelayanannya agar masyarakat yang dilayani lebih terpuaskan. Mengingat bahwa di samping faktor kualitas pelayanan dan faktor semangat kerja pegawai, masih ada beberapa faktor yang dapat mempengaruhi kepuasan masyarakat yang dilayani, maka Kantor Camat Bayung Lencir Kecamatan Bayung Lencir Kabupaten Musi Banyuasin perlu memperhatikan pula faktor-faktor lain seperti kurang tersedianya formulir, kurangnya alat transportasi dan minimnya dana operasional yang dapat menghambat kinerja dari pegawai Kantor Camat Bayung Lencir Kecamatan Bayung Lencir Kabupaten Musi Banyuasin.
\end{abstract}

Kata kunci; Kualitas, Semangat Kerja dan Kualitas Pelayanan terhadap Kepuasan Kerja

\section{PENDAHULUAN}

\section{Latar Belakang Masalah}

Seorang pegawai mampu memberikan pelayanan yang tinggi maka masyarakat akan merasa puas, sebaliknya jika kualitas pelayanan yang diberikan rendah, maka masyarakat yang membutuhkan pelayanan akan merasa tidak puas. Kualitas pelayanan dapat dinyatakan sebagai perbandingan antara pelayanan yang diharapkan dengan pelayanan yang diterimanya (Parasuraman, Zeithami, dan Berry, 1995:240). Berdasarkan kondisi tersebut dapat dipahami bahwa kepuasan masyarakat dapat dipengaruhi oleh tingkat kualitas 
pelayanan yang diberikan pegawai, sedangkan semangat kerja pegawai dapat mempengaruhi kepuasan masyarakat.

Kantor Camat Bayung Lencir merupakan salah satu contoh instansi yang harus memberikan pelayanan kepada masyarakat yang membutuhkan kelengkapan administrasi, surat-surat dan sebagainya, Kantor Camat Bayung Lencir Kabupaten Musi Banyuasin sebagai instansi pemerintah yang bertugas memberikan pelayanan umum senantiasa dituntut untuk bekerja secara optimal melayani masyarakat.

Pada kenyataannya tidak semua pegawai Kantor Camat Bayung Lencir mampu memberikan pelayanan yang baik kepada masyarakat, demikian pula halnya dengan semangat kerja pegawai, tidak setiap pegawai memiliki semangat kerja yang tinggi.

\section{Rumusan Masalah}

Rumusan masalah dalam penelitian ini adalah adakah pengaruh kualitas dan semangat kerja pegawai terhadap kepuasan masyarakat pada pelayanan di Kantor Camat Bayung Lencir Kecamatan Bayung Lencir Kabupaten Musi Banyuasin ?

\section{Tujuan Penelitian}

Tujuan yang ingin dicapai dalam penelitian ini adalah untuk mengetahui pengaruh kualitas pelayanan dan semangat kerja pegawai terhadap kepuasan masyarakat pada pelayanan di Kantor Camat Bayung Lencir Kecamatan Bayung Lencir Kabupaten Musi Banyuasin.

\section{KAJIAN PUSTAKA}

1. Teori

\section{a. Kualitas Pelayanan}

Secara etimologi tidak mudah mendefinisikan atau memberikan pengertian mengenai kualitas. Namun demikian ada beberapa definisi umum yang diberikan oleh beberapa pakar kualitas. Josep M. Juran (Tjiptono, 2004:11) bahwa kualitas adalah kecocokan untuk pemakaian (fitness for use). Taguchi (Tjiptono, 2004 : 12) bahwa kualitas adalah kerugian yang ditimbulkan oleh suatu produk bagi masyarakat setelah produk tersebut dikirim, selain kerugiankerugian yang disebabkan fungsi intrinsik produk.

Secara sederhana pengertian kualitas pelayanan dapat dinyatakan sebagai perbandingan antara pelayanan yang diharapkan konsumen dengan pelayanan yang diterimanya (Parasuraman, Zeithami, dan Berry, 1995: 240) menurut Zethami, Berry dan Parasuraman (dalam Tjiptono, 2004: 12) kualitas yang dirasakan didefinisikan sebagai penilaian konsumen terhadap keseluruhan keunggulan produk, sedangkan kualitas pelayanan yang dirasakan merupakan pertimbangan global yang berhubungan dengan superioritas dari pelayanan.

Apabila layanan yang diterima atau dirasakan sesuai dengan yang diharapkan konsumen, maka kualitas layanan dipersepsikan sebagai kualitas ideal, tetapi sebaliknya jika layanan yang diterima atau dirasakan lebih rendah dari pada yang diharapkan, maka kualitas layanan dipersepsikan buruk. Terdapat 5 (lima) determinan kualitas jasa yang dapat dirincikan sebagai berikut :

a. Keandalan (reliability), yaitu kemampuan untuk melaksanakan jasa yang dijanjikan dengan tepat dan terpercaya.

b. Ketanggapan (responsiveness), yaitu kemampuan untuk membantu pelanggan dan memberikan jasa dengan cepat 
c. Keyakinan (confidence), yaitu pengetahuan dan kesopanan pegawai serta kemampuan mereka untuk menimbulkan kepercayaan dan keyakinan atau "assurance"

d. Empati (emphaty), yaitu syarat untuk peduli, memberi perhatian pribadi bagi pelanggan.

e. Berwujud (tangible), yaitu penampilan fasilitas fisik, peralatan, personel, dan media komunikasi.

Alex Nitisemito (1991 160) berpendapat bahwa: "Semangat kerja adalah melakukan pekerjaan secara lebih giat sehingga dengan demikian pekerjaan akan diharapkan lebih cepat dan lebih baik." Dari pengertian tersebut jika seorang karyawan mempunyai moral kerja yang tinggi,maka akan mempunyai kesediaan perasaan untuk melakukan pekerjaan dengan lebih cepat dan semangat untuk mencapai hasil yang lebih baik. Selanjutnya Alexander Leigton yang dikutip Moekijat (1989 130) menambahkan bahwa: "Semangat kerja atau moril kerja adalah kemampuan sekelompok orang untuk bekerja sama dengan giat dan konsekuen dalam mengejar tujuan bersama".

Dari 2 (dua) definisi tentang semangat kerja tersebut diatas dapat disimpulkan bahwa semangat kerja merupakan sikap mental individu atau kelompok yang terdapat dalam suatu organisasi yang menunjukkan rasa kegairahan di dalam melaksanakan tugastugas atau pekerjaan dan mendorong mereka untuk bekerja secara lebih baik dan lebih produktif.

\section{c. Pengertian Kepuasan Masyarakat}

Menurut TSe dan Wilton (dalam Tjiptono,2004 :146) disebutkan bahwa kepuasan atau ketidakpuasan pelanggan adalah respon pelanggan terhadap evaluasi ketidaksesuaian yang dirasakan antara harapan sebelumnya dan kinerja aktual produk setelah pemakaiannya. Kepuasan pelanggan merupakan fungsi dari harapan dan kinerja. Oliver (dalam Tjiptono, 2004 : 146) memberikan pendapat bahwa kepuasan keseluruhan ditentukan oleh ketidaksesuaian harapan yang merupakan perbandingan antara kinerja yang dirasakan dengan harapan. Kepuasan merupakan fungsi positif dari harapan pelanggan dan keyakinan diskonfirmasi. Dengan demikian kepuasan atau ketidakpuasan masyarakat merupakan respon dari perbandingan antara harapan dan kenyataan.

Kotler (dalam Tjiptono, (2004:147) memberikan definisi kepuasan pelanggan sebagai perasaan senang atau kecewa seseorang yang berasal dari perbandingan antara kesannya terhadap kinerja (atau hasil) suatu produk dan harapanharapannya.

Menurut Fandy Tjiptono dan Gregorius Chandra (2006:130) ada empat metode untuk mengukur kepuasan pelanggan, yaitu :

1. Sistem Keluhan dan Saran

2. Survei Kepuasan Pelanggan

3. Ghost Shopping (Pelanggan Bayangan)

4. Analisa Pelanggan yang Beralih

\section{Penelitian Sebelumnya}

1. Peneliti yang dilakukan oleh Pratiwi (2006), dengan judul "Peran Upah, Gaji, dan Insentif terhadap Motivasi Kerja Pegawai pada Badan Pemberdayaan Masyarakat dan Keluarga Berencana (BPMKB) Kota Bogor. Hasilnya adalah: (1) Adanya pengaruh yang signifikan antara upah, gaji, dan insentif secara simultan terhadap motivasi kerja pegawai pada 
BPMKB Kota Bogor, dan (2) Adanya pengaruh yang signifikan antara upah, gaji, dan insentif secara parsial terhadap motivasi kerja pegawai pada BPMKB Kota Bogor.

2. Puji, Sungkono, dan Cynthia (2013), dengan judul Pengaruh Pengembangan Karir terhadap Motivasi Kerja Pegawai pada PT.Excel Utama Indonesia Karawang. Hasil penelitiannya adalah (1) Pengembangan Karir berpengaruh positif dan signifikan $(\alpha=5 \%)$ terhadap Motivasi Kerja pegawai PT. Excel Utama Indonesia Karawang, Dengan nilai koefisien determinasi sebesar 49 persen, artinya pengaruh Pengembangan Karir terhadap Motivasi Kerja Pegawai adalah 49 persen sedangkan sisanya 51 persen dipengaruhi oleh faktor-faktor lain yang tidak diteliti dalam penelitian ini.

3. Penelitian yang dilakukan oleh Kurnia (2013), dengan judul Pengaruh Insentif Terhadap Motivasi dan Kinerja. Berdasarkan hasil analisis menunjukkan bahwa (1) Variabel insentif materiil berpengaruh signifikan terhadap motivasi kerja sebesar 0,452; (2) Variabel insentif non materiil berpengaruh signifikan terhadap motivasi kerja sebesar 0,418; (3) Variabel insentif materiil mempunyai pengaruh langsung yang signifikan terhadap kinerja karyawan dengan nilai koefisien path sebesar 0,278 dan pengaruh tidak langsung sebesar 0,157; (4) Variabel insentif non materiil mempunyai pengaruh langsung yang signifikan terhadap kinerja karyawan dengan nilai koefisien path sebesar 0,265 dan pengaruh tidak langsung sebesar 0,145 ; (5) Variabel motivasi kerja mempunyai pengaruh yang signifikan dengan nilai koefisien path sebesar 0,348 terhadap variabel kinerja karyawan.

4. Penelitian yang dilakukan oleh Alwi Suddin dan Sudarman (2010), dengan judul Pengaruh Kepemimpinan, Motivasi, dan Lingkungan Kerja terhadap Kinerja Pegawai Kecamatan Laweyan Kota Surakarta. Hasil analisis diperoleh (1) ada pengaruh yang signifikan kepemimpinan terhadap kinerja pegawai Kecamatan Laweyan Kota Surakarta, (2) ada pengaruh yang signifikan motivasi terhadap kinerja pegawai Kecamatan Laweyan Kota Surakarta, (3) ada pengaruh yang signifikan lingkungan terhadap kinerja pegawai Kecamatan Laweyan Kota Surakarta, dan (4) ada pengaruh yang signifikan kepemimpinan, motivasi dan lingkungan secara simultan terhadap kinerja pegawai Kecamatan Laweyan Kota Surakarta.

5. Penelitian yang dilakukan oleh Nafrizal, Rahman, dan Sofyan (2012), dengan judul Pengaruh Insentif, Motivasi Kerja, Gaya Kepemimpinan dan Budaya Organisasi terhadap Kepuasan Kerja serta Dampaknya pada Kinerja Personil POLRI pada Satuan Kerja Biro Operasi Mapolda Aceh. Hasil penelitian diperoleh penjelasan bahwa (1) insentif, motivasi kerja, gaya kepemimpinan dan budaya organisasi baik secara parsial maupun simultan berpengaruh terhadap kepuasan kerja personil Polri pada Satuan Kerja Biro Operasi Polda Aceh, (2) insentif, motivasi kerja, gaya kepemimpinan dan budaya organisasi baik secara parsial maupun simultan berpengaruh terhadap kinerja personil Polri pada Satuan Kerja Biro Operasi Polda Aceh, (3) insentif, motivasi kerja, gaya kepemimpinan dan budaya organisasi mempunyai 
pengaruh tidak langsung terhadap kinerja melalui kepuasan kerja personil Polri pada Satuan Kerja Biro Operasi Polda Aceh dan (4) kepuasan kerja berpengaruh secara signifikan terhadap kinerja personil Polri pada Satuan Kerja Biro Operasi Polda Aceh.

\section{KerangkaPemikiran}

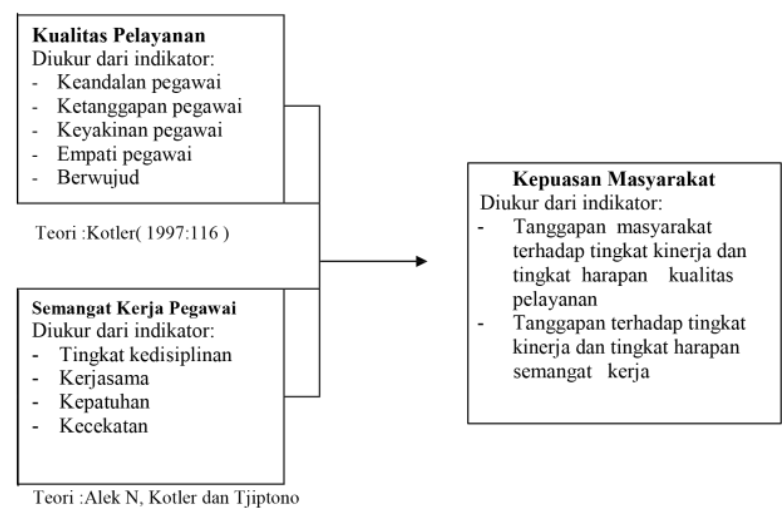

\section{Gambar1KerangkaBerfikir}

\section{Hipotesis}

Hipotesis dalampenelitian ini adalah "Ada pengaruh kualitas dan semangat kerja pegawai terhadap kepuasan masyarakat pada pelayanan di Kantor Camat Bayung Lencir Kecamatan Bayung Lencir Kabupaten Musi Banyuasin".

\section{Metode Penelitian}

\section{Tempat Penelitian}

Tempat penelitian adalah masyarakat yang berinteraksi dengan Kantor Camat Bayung Lencir Kecamatan Bayung Lencir Kabupaten Musi Banyuasin.

\section{Metode Penelitian}

\section{a. Desain Penelitian}

Desain penelitian yang digunakan dalam penelitian ini adalah penelitian kuantitatif korelasional. Penelitian kuantitatif bekerja dengan angka yang datanya berwujud bilangan yang dianalisis dengan menggunakan statistik untuk menjawab pertanyaan atau hipotesis penelitian yang sifatnya spesifik dan untuk melakukan prediksi bahwa suatu variabel tertentu mempengaruhi variabel lainnya.

\section{b. Data}

1. Sumber data dalam penelitian ini adalah data primer, yang diperoleh dari hasil pembagian kuesioner kepada masyarakat yang melakukan urusan di Kantor Camat Bayung Lencir Kecamatan Bayung Lencir Kabupaten Musi Banyuasin.

2. Skala Pengukuran yang berbentuk likert. Data yang diperoleh adalah data interval, dan biasanya skala ini digunakan untuk mengukur sikap/karakteristik tertentu yang dipunyai oleh seseorang.

\section{Variabel}

a. Kualitas Pelayanan (X1) diukur dari indikator :

1) Keandalan pegawai, yaitu kemampuan untuk melaksanakan jasa yang dijanjikan dengan tepat dan terpercaya.

2) Ketanggapan pegawai, yaitu kemampuan untuk membantu pelanggan dan memberikan jasa dengan cepat.

3) Keyakinan pegawai, yaitu pengetahuan dan kesopanan pegawai serta kemampuan mereka untuk menimbulkan kepercayaan dan keyakinan atau "assurance"

4) Empati pegawai, syarat untuk peduli, memberi perhatian pribadi bagi pelanggan

5) Berwujud (penampilan fisik), yaitu penampilan fasilitas fisik, 
peralatan, personel, dan media komunikasi.

b. Semangat kerja (X2) diukur dari indikator :

1) Tingkat kedisiplinan

2) Kerjasama

3) Kepatuhan

4) Kecekatan

c. Variabel (Y) adalah terikat (dependen) atau variabel terpengaruh. Variabel Y. Dalam penelitian ini adalah Kepuasan Masyarakat diukur dari indikator:

a. Tanggapan masyarakat yang meliputi tingkat kinerja dan tingkat harapan terhadap kualitas pelayanan

b. Tanggapan masyarakat yang meliputi tingkat kinerja dan tingkat harapan terhadap semangat kerja pegawai

\section{Populasi dan Sampel}

\section{Populasi}

Populasi dalam penelitian ini adalah keseluruhan masyarakat yang datang ke Kantor Camat Bayung Lencir Kabupaten Musi Banyuasin untuk mendapatkan pelayanan umum selama satu bulan yang berjumlah sekitar 500 orang.

\section{Sampel}

Besarnya sampel yang diambil dihitung dengan menggunakan metode Solvin yaitu :

$$
\begin{aligned}
& \mathrm{n}=\frac{\mathrm{N}}{1+\mathrm{Ne}^{2 \ldots \ldots \ldots \ldots . . . \quad(N a z i r, 2009)}} \\
& \mathrm{n}=\text { Jumlah sampel } \\
& \mathrm{N}=\text { Populasi } \\
& \mathrm{e}=\text { batas toleransi kesalahan }
\end{aligned}
$$

Dalam penelitian ini Popualsi $(\mathrm{N})=$ 500 dan e atau batas toleransi kesalahan $10 \%(\alpha=10 \%)$ sehingga sampelnya dihitung sebagai berikut :

$$
\begin{aligned}
& \mathrm{N}=500 / 1+500(0,1)^{2} \\
& \mathrm{~N}=500 / 1+500(0,01) \\
& \mathrm{N}=500 / 5=100
\end{aligned}
$$

Sampel penelitian ini adalah 100 orang masyarakat yang mengurus administrasi kependudukan di kantor Camat Bayung Lencir Kabupaten Musi Banyuasin.

\section{Teknik Pengumpulan Data}

Pengumpulan data yang menggunakan kuesioner (angket), Sebagai alat bantu yang ditujukan kepada responden. Hasilhasil jawaban atau tanggapan dari respoden dalam menjawab kuesioner masih bersifat kualitatif. Oleh karena itu, untuk dapat dianalisis secara kuantitatif maka jawaban diberi skor berdasarkan skala interval dengan metode Likert. Skala Likert mempunyai interval 1-5. Untuk jawaban yang mendukung pertanyaan atau pernyataan diberi skor tertinggi dan untuk jawaban yang tidak mendukung pertanyaan atau pernyataan diberi skor terendah.

a. Untuk jawaban Sangat Setuju, diberi nilai 5

b. Untuk jawaban Setuju diberi nilai 4.

c. Untuk jawaban Netral diberi nilai 3.

d. Untuk jawaban yang Tidak Setuju diberi nilai 2.

e. Untuk jawaban Sangat Tidak Setuju diberi nilai 1 .

\section{Metode Analisis}

Model statistik ini dipilih karena penelitian ini dirancang untuk meneliti variabel-variabel bebas yang berpengaruh terhadap variabel terikat,dengan data yang digunakan disebut data cross section yang dirumuskan sebagai berikut :

$$
\mathrm{Y}=\mathrm{a}+\text { bit1Xit } 1+\text { bit2Xit } 2+\varepsilon i t
$$


Dimana :

$\begin{array}{ll}\mathrm{Y} & =\text { Kepuasan Masyarakat } \\ \mathrm{a} & =\text { Konstanta } \\ \text { bit1...bit3 } & =\text { Koefisien Regresi } \\ \text { Xit1 } & =\text { Kualitas Pelayanan } \\ \text { Xit2 } & =\text { Semangat Pegawai } \\ \text { Eit } & =\text { Error of Term }\end{array}$

\section{Hasil dan Pembahasan Penelitian 1 Hasil Penelitian}

1 Model Analisis

Berikut disajikan hasil persamaan regresi.

\begin{tabular}{lllll} 
Variable & Coefficient & Std. Error & t-Statistic & Prob. \\
\hline \hline X1 & 0.302457 & 0.117749 & 2.568659 & 0.0119 \\
X2 & 0.241801 & 0.112415 & 2.150976 & 0.0343 \\
$\mathrm{C}$ & $1,4718.87$ & 5230.777 & 2.813898 & 0.0061 \\
\hline \hline \multirow{2}{*}{ R-squared } & 0.243679 & Mean dependent var & 42000.00 \\
Adjusted R-squared & 0.217296 & S.D. dependent var & 6217.048 \\
S.E. of regression & 5500.258 & Akaike info criterion & 20.10640 \\
Sum squared resid & $2.60 \mathrm{E}+09$ & Schwarz criterion & 20.21751 \\
Log likelihood & -900.7882 & Hannan-Quinn criter. & 20.15121 \\
F-statistic & 9.236120 & Durbin-Watson stat & 1.507482 \\
Prob(F-statistic) & 0.000023 & & \\
\hline \hline
\end{tabular}

Hasil Persamaan Regresi

$Y=1,4718+0,3024 X_{1}+0,2418 X_{2}$

Dari persamaan regresi diatas dapat dijelaskan sebagai berikut :

a. Nilai konstanta sebesar 1,4718 , hal ini menunjukan bahwa apabila variabel $\mathrm{X}_{1}$, $\mathrm{X}_{2}$ nilainya 0 maka nilai $\mathrm{Y}=1,4718$

b. Nilai koefisien $\mathrm{X}_{1}$ (kualitas pelayanan) nilainya sebesar 0,3024. Hal ini membuktikan bahwa apabila nilai X1 meningkat sebesar 1 satuan atau $100 \%$ maka nilai variabel (Y) akan mengalami peningkatan sebesar 0,3024 dengan asumsi variabel independen lainnya konstan.

c. Nilai koefisien $\mathrm{X}_{2}$ (semangat pegawai) nilainya sebesar 0.2418. Hal in membuktikan bahwa apabila nilai X2 meningkat 1 satuan atau $100 \%$ maka nilai variabel (Y) akan mengalami kenaikan sebesar 0.2418 dengan asumsi variabel independen lainnya konstan.

\section{Analisis Koefisien Determinasi}

Berikut disajikan hasil uji koefisien determinasi (R Squared).

\begin{tabular}{l|l|r|r|r|}
\hline Model & R & R Square & $\begin{array}{l}\text { Adjusted } \\
\text { R Square }\end{array}$ & $\begin{array}{l}\text { Durbin- } \\
\text { Watson }\end{array}$ \\
\hline 1 &, $494^{\mathrm{a}}$ &, 244 &, 217 & 1,507 \\
\hline
\end{tabular}
a. Predictors: (Constant), x1, x2
b. Dependent Variable: $\mathrm{y}$

Berdasarkan hasil uji koefisien determinasi ( $\mathrm{R}$ Squared) diperoleh nilai sebesar 0,244 atau $24,4 \%$ variabel kepuasan masyarakat (Y) mampu dijelaskan oleh variabel kualitas pelayanan (X1) dan semangat pegawai (X2), sedangkan $75,6 \%$ dipengaruhi oleh faktorfaktor lain diluar penelitian ini.

\section{Pembahasan}

a. Pengaruh Kualitas Pelayanan terhadap Kepuasan Masyarakat

Hipotesis dapat diterima yaitu kualitas pelayanan berpengaruh positif dan signifikan terhadap kepuasan masyarakat. Secara umum penelitian ini menunjukkan hasil yang cukup memuaskan. Hasil analisis deskriptif menunjukkan bahwa kualitas pelayanan yang diberikan oleh Kantor Camat Bayung Lencir Kecamatan Bayung Lencir Kabupaten Musi Banyuasin secara umum sudah baik. Hal ini dapat ditunjukkan dari banyaknya tanggapan kepuasan yang tinggi dari responden terhadap kondisi dari masing-masing variabel penelitian. Dari hasil tersebut selanjutnya diperoleh bahwa variabel kualitas pelayanan dalam kelima dimensinya memiliki pengaruh yang 
positif dan signifikan terhadap kepuasan konsumen. Hal ini dikarenakan bahwa dengan pemberian pelayanan yang berkualitas, maka hal tersebut akan menciptakan kepuasan dalam diri masyarakat.

b. Pengaruh Semangat Kerja terhadap Kepuasan Masyarakat

Hipotesis dapat diterima yaitu semangat kerja. Semangat kerja merupakan sikap mental individu atau kelompok yang terdapat dalam suatu organisasi yang menunjukkan rasa kegairahan di dalam melaksanakan tugas-tugas atau pekerjaan dan mendorong mereka untuk bekerja secara lebih baik dan lebih produktif. Jika hasil perhitungan tersebut dikaitkan dengan semangat kerja petugas Kantor Camat Bayung Lencir Kecamatan Bayung Lencir Kabupaten Musi Banyuasin dalam melayani masyarakat umum, maka petugasyang memiliki semangat kerja yang tinggi akan dapat meningkatkan prestasi kerjanya dan dapat memberikan kepuasan dalam melayani masyarakat, karena bekerja dengan penuh gairah dalam menjalankan tugas.

\section{V.Simpulan dan Rekomendasi}

\section{Simpulan}

Pengaruh kualitas pelayanan dan semangat kerja terhadap kepuasan masyarakat Kantor Camat Bayung Lencir Kecamatan Bayung Lencir Kabupaten Musi Banyuasin, dapat diambil kesimpulan bahwa hasil pengujian menunjukan ada pengaruh yang signifikan antara kualitas pelayanan dan semangat kerja terhadap kepuasan masyarakat di Kantor Camat Bayung Lencir Kecamatan Bayung Lencir Kabupaten Musi Banyuasin.

\section{Rekomendasi}

Kualitas pelayanan memiliki pengaruh yang lebih kecil dibandingkan dengan semangat kerja karyawan, sehingga Kantor Camat Bayung Lencir Kecamatan Bayung Lencir Kabupaten Musi Banyuasin perlu meningkatkan kualitas pelayanannya agar masyarakat yang dilayani lebih terpuaskan. Mengingat bahwa di samping faktor kualitas pelayanan dan faktor semangat kerja pegawai, masih ada beberapa faktor yang dapat mempengaruhi kepuasan masyarakat yang dilayani, maka Kantor Camat Bayung Lencir Kecamatan Bayung Lencir Kabupaten Musi Banyuasin perlu memperhatikan pula faktorfaktor lain seperti kurang tersedianya formulir, kurangnya alat transportasi dan minimnya dana operasional yang dapat menghambat kinerja dari pegawai Kantor Camat Bayung Lencir Kecamatan Bayung Lencir Kabupaten Musi Banyuasin.

\section{Daftar Pustaka}

Arikunto Suharsimi, 1998, Metode Penelitian Suatu pendekatan Praktek. Edisi Revisi Rineka Cipta, Jakarta.

Moekijat, 1989, Manajemen Tenaga Kerja dan Hubungan Kerja, Pionir, Bandung

Nitisemito, Alex S., 1991, Manajemen Personalia. Ghalia Indonesia. Jakarta.

Parasuman, Zeithami dan Berry, 1988, Communication and Control Processes in the Delivery of Service Quality, Journal of Marketing vol 52 
Sudjana, 2001, Metoda Statistika, Tarsito, Bandung

Supranto J, 2001, Pengukuran Tingkat Kepuasan Pelanggan, Rineka Cipta, Jakarta

Tjiptono, Fandy, 2004, ManajemenJasa, Andi, Yogyakarta

Tjiptono, Fandy dan Diana Anastasia, 2000, Total Quality Management, Andi, Yogyakarta

Zainun Buchari, 1981, Manajemen Personalia, Penerbit Balai Aksara, Jakarta. 